\title{
練り混ぜ時間が壁土の強度特性 EFFECT OF MIXING TIME ON に及ぼす影響 \\ DEFORMATION AND STRENGTH OF WALL CLAY
}

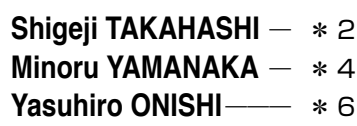

The mixing time of wall clay is decided based on experience and intuition of plasterers. There is no clear description about the mixing time of wall clay. In this study, the load electric power of bi-axial forced mixer is measured to grasp the optimal mixing time of wall clay. The influence of mixing time on the mechanical characteristics of wall clay is examined based on the unconfined compression tests for every mixing time. As a result, the optimal mixing time of wall clay with much clay fraction is estimated to be about 50 minutes in the range of this study.

\section{1.はじめに}

土塗壁に用いられる壁土は, 身近に採取できる粘性のある土と葍 すさ等の繊維材, 塗り層に応じて砂を混ぜ合わせたものである。壁 土の製造は一軸土練機や二軸強制練りミキサーで行われ，製造業者 の経験と勘で水量や練り混ぜ時間が決められている。壁土の練り混 ぜについて文献 1)では,「荒壁土は水とよく混練りしてから蒠すさ を混ぜ，粘土が多くて粘性のはなはだしいときは砂を適量補い，よ く切り返しながら粘土の小塊を砕きつつよく混ぜる」と示されてい る。練り混ぜ時間に対する明確な基準が無いことから, 練り混ぜ時 間が壁土の強度特性に及ぼす影響を定量的に評価し, 適切な練り混 ぜ時間を検討する必要がある。

壁土の調查研究として中村 ${ }^{2)}$ は日本壁の品質を調査し, 荒壁土の 処理，水合せ，混ぜ合わせについて報告している。蒲田ら 3) と濱崎 ら ${ }^{4)}$ は水合せ期間が壁土の強度特性に及ぼす影響について実験を行 い，水合せ期間が長くなると壁土の曲げ，圧縮及びせん断強度が向 上することを報告している。平野ら 5)は壁土の練り置き期間に生ず る変化が材料特性に及ぼす影響について実験的研究を行い, 練り置 きを行うことでばらつきを抑えながら強度を上昇させ，勒性を確保 することが可能であることを示している。興石ら 6) 99) は壁土の性質 に関する研究を行い, 左官職人が調整した練り土の水量とすさ量を 求め, 試験に用いる壁土試料を作製する手順及び方法を定めている。 さらに，壁土の性質を総合的に向上させる調合条件の検討を行って いる。

以上のように，菜すさを調合した壁土の練り置きや水合せ期間に 対する力学的性質の検討が行われている。一方，二軸強制練りミキ サーで壁土を製造した場合には，水合せや練り置きが行われること はほとんどないため, 練り混ぜ時間に対する力学的性質の変化につ
いて定量的評価を行う必要がある。

本論文では, 日本各地で産出される壁土の製造方法と土質基本物 理特性の把握を行う。その中で, 粘土分を多く含む壁土は, 練り混 ぜ水を吸着水として粘土粒子相互間に一様に分散させるために, 練 り混ぜ時間を長く寸る必要がある。そこで, 水合せや練り置きを行 わない葈すさを調合した壁土の適切な練り混ぜ時間の把握を目的と して, 菜すさ調合後の練り混ぜ時間と二軸強制練りミキサーの負荷 電力の測定を行う。同時に練り混ぜ開始後 5 分から 70 分までの間 で試料採取を行い, 壁土の一軸圧縮試験から壁土のせん断強度に影 響を及ぼす粘着力とせん断抵抗角を定量的に評価し, 練り混ぜ時間 が壁土の強度特性に及ぼす影響について検討を行う。さらに, 本実 験の範囲であるが, 壁土の適切な練り混ぜ時間についても検討する。

\section{2. 壁土の地域特性}

土塗壁に用いられる壁土の物理的特性は産出地によって異なる。 壁土は莕すさを調合して用いられ，その製造方法も地域で異なる。 主な地域の荒壁塗りに用いる壁土の製造方法を表 1 に示す。壁土製 造所では主に二軸強制練りミキサーと一軸土練機で練り混ぜが行わ れ, 埼玉を除いて, 葍すさの調合も同時に行われている。図 1 に文 献 10)で求められた各地の壁土の粒度分布を示す。地域によって粒 度分布は大きく異なり, 埼玉, 福井, 岐阜, 熊本は粒径が $0.005 \mathrm{~mm}$ 以下の粘土と 0.005 0.075mm のシルトの細粒分を多く含んでいる。 特に, 熊本は細粒分の中でも粘土の占める割合が $62 \%$ あり, 他の 地域と粒度分布が大きく異なる。表 2 に各地の壁土の土質基本物理 特性を示す。土粒子密度 $\rho_{s}$ は $2.57 \sim 2.82 \mathrm{~g} / \mathrm{cm}^{3}$ に分布している。コ ンシステンシーは液体から塑性体に移る境界の含水比を示寸液性限 界 $W_{L}$, 塑性体から半固体に移る境界の含水比を示寸塑性限界 $W_{P}$
本稿は文献 10)，15）を再構成し，加筆・修正したものである。 四国職業能力開発大学校住居環境科 准教授・博士 (工学) (干 763-0093 丸亀市郡家町 3202 番地）

2 (有)ビス計画

3 香川大学工学部安全システム建設工学科 助教・博士 (工学)

香川大学工学部安全システム建設工学科 准教授・博士（工学）

香川大学工学部安全システム建設工学科 教授・工博

(有)田園都市設計
Assoc. Prof., Dept. of Residential Environment, Shikoku Polytechnic College, Dr. Eng.

*2 VIS Structural Design

*3 Research Assoc., Dept. of Safety Systems Construction Eng., Kagawa Univ., Dr Eng.

*4 Assoc. Prof., Dept. of Safety Systems Construction Eng., Kagawa Univ., Dr. Eng.

5 Prof., Dept. of Safety Systems Construction Eng., Kagawa Univ., Dr. Eng.

Denen-toshi Design \& Planning 
で表される。同一体積において粘土粒子が多くなると土粒子の表面 積が大きくなり, 液性限界 $W_{L}$ が大きくなる。シルトや砂粒子が多 くなると液性限界 $W_{L}$ が小さくなる。粘土分が多いと液性限界 $W_{L}$ と塑性限界 $W_{P}$ の差を示寸塑性指数 $I_{p}$ は大きくなる。熊本は粘土分 を多く含むため, 他の地域と比べて液性限界が 1.7 2.9 倍, 塑性限 界が 1.5 2.4 倍大きい。熊本の塑性指数 $I_{p}$ は 45.2 であり, 他の地 域の $1.7 \sim 10.3$ 倍を示している。

\section{3. 実験概要}

粘土分を多くむ壁土の場合, 練り混ぜによる強度増加が大きいと 考えられ，練り混ぜ水を吸着水として粘土粒子相互間に分散させる ためには, 練り混ぜ時間がある程度必要と考えられる。そこで, 練 り混ぜ時間が最も必要であると思われる粘土分を多く含んでいる熊 本の壁土について, 壁土製造所のミキサーの電動機の負荷電力の計 測を行い, 練り混ぜ時間の経過による粘性の変化を把握する。一定 の練り混ぜ時間ごとに壁土試料を採取し, 一軸圧縮試験を行い, 練 り混ぜ時間が壁土の強度特性に与える影響について検討する。

\section{1 菜すさを調合した壁土の強度特性}

既往の研究 ${ }^{11)} よ り$, 葍すさ調合量が少ない場合には図 2 に示すよ うに圧縮強度が大きくなり, 圧縮強度以降の応力度低下が大きくな る強度指向型の挙動を示す。菜すさ調合量が多くなると供試体中の 土粒子量が低下寸るため圧縮強度が低下し, 繊維補強効果により圧 縮強度以降の応力度低下が小さくなる勒性指向型の挙動を示す。蒠 すさ調合量の増加により壁土のせん断強度に影響を及ぼす強度定数 の粘着力 $c$ が低下寸る。ミキサーで練り混ぜを長い時間行った場合 には, 葈すさが開繊し, 土粒子量が増加するため, 葍すさ混合量が 同じ場合には粘着力 $c$ の向上が期待できる。

\section{2 使用材料}

壁土は熊本県宇城市で産出されるものを用いた。今回対象とした 壁土製造所では, 採取した壁土を製造所屋外の上家のないストック 場で保管して使用していた。採取時の壁土は湿潤状態であった。蒠 すさは熊本県産の稲葍を使用し, 壁土製造所において写真 1 に示す
長さ $4 \sim 10 \mathrm{~cm}$ 程度に切断したものを使用した。

\section{3 調合方法}

壁土の調合は荒壁塗り用とし, 菜すさと練り混ぜ水の調合を職人 に行ってもらった。壁土の砂等による粒度調整は行わなかった。壁 土の練り混ぜに用いた二軸強制練りミキサーは写真 2 に示すような 公称容量 $2.6 \mathrm{~m}^{3}$, 電動機出力 $22 \mathrm{~kW}$ であった。材料の投入順序は壁 土を 4 回に分けて二軸強制練りミキサーに入れ， 1 回目の壁土の投 入後に加水を行った。 2 回目と 3 回目の壁土の投入後に水量を落と し, 葍すさを投入した。その後 4 回目の壁土の投入を行い, ミキシ ングパドル回転時に職人の目視によってミキシングパドルに付着す る壁土の粘性が確認され, 粘性が高いと判断した場合には写真 3 に 示寸ように適宜加水が行われた。

\section{4 試料採取方法}

職人への事前の聞き取り調查により, 葈すさ調合後, 概称 40 分 程度の練り混ぜ時間が壁土塗りには適切とされている。練り混ぜ時 間の測定起点を葍すさを投入して加水が終了した後とする。試料採 取は練り混ぜ開始後 40 分までは 5 分ごと, 40 分以降は 10 分ごと に 70 分まで行った。試験体は全部で 11 種類である。試験体数はば らつきを考えて各 5 体である。

\section{5 測定項目}

図 3 に測定フローを示す。練り混ぜ前の壁土を壁土製造所におい て採取し, 密封容器に保管して実験場に持ち帰り, 含水比, 粒度分 布, 液性限界・塑性限界等の物理特性試験を行った。電力計を用い て, 营すさを調合した壁土の練り混ぜ時における二軸強制練りミキ サーの電動機の負荷電力を 1 秒間隔で測定した。練り混ぜ後の壁土 も同様に持ち帰り, 含水比試験及び文献 12 )に基づき, 直径 $12.5 \mathrm{~cm}$, 高さ $25 \mathrm{~cm}$ の円柱形型枠を用いて供試体を作製した。壁土の型枠へ の充填は振動を与えながら行った。供試体を脱型後, 気乾状態とな るまで養生し, 写真 4 に示す一軸圧縮試験を行った。文献 13)に準 じて毎分 $1 \%$ の圧縮ひずみが生じる割合で加力を行った。壁土のせ ん断強度に影響を及ぼすせん断抵抗角 $\phi$ 及び粘着力 $c$ の強度定数は 文献 12)より式(1)及び(2)から求めた。
表 1 壁土試料の製造方法

\begin{tabular}{|c|c|c|}
\hline 地域 & 原土の採取地 & 練り混ぜ方法 \\
\hline 埼玉 & 埼玉県鴻巣市 & 左官職人 \\
\hline 福井 & 福井県越前市 & 一軸土練機 \\
\hline 岐阜 & 岐阜県多治見市 & 二軸強制練り伡州一 \\
\hline 京都 & 京都市伏見区媣草 & 一軸土練機 \\
\hline 香川 & 香川県三豊市 & 一軸土練機 \\
\hline 山口長門 & 山口県長門市 & 一軸土練機 \\
\hline 山口防府 & 山口県防府市 & 一軸土練機 \\
\hline 熊本 & 熊本県宇城市 & 二軸強制練り、泮一 \\
\hline
\end{tabular}

表 2 土質基本物理特性 10)

\begin{tabular}{|c|c|c|c|c|c|c|c|c|c|}
\hline \multicolumn{2}{|c|}{ 供試体名 } & 埼玉 & 福井 & 岐阜 & 京都 & 香川 & $\begin{array}{l}\text { 山口 } \\
\text { 長門 }\end{array}$ & $\begin{array}{l}\text { 山口 } \\
\text { 防府 }\end{array}$ & 熊本 \\
\hline \multicolumn{2}{|c|}{$\begin{array}{l}\text { 土粒子密度 } \\
\rho_{s}\left(\mathrm{~g} / \mathrm{cm}^{3}\right)\end{array}$} & 2.61 & 2.68 & 2.58 & 2.64 & 2.61 & 2.57 & 2.59 & 2.82 \\
\hline \multirow{3}{*}{ 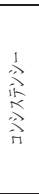 } & $\begin{array}{c}\text { 液性限界 } \\
W_{L}(\%)\end{array}$ & 29.7 & 41.8 & 50.5 & 32.1 & 42.8 & 44.4 & 36.6 & 84.8 \\
\hline & $\begin{array}{c}\text { 塑性限界 } \\
w_{p}(\%)\end{array}$ & 25.3 & 24.3 & 24.3 & 16.5 & 20.1 & 26.4 & 21.0 & 39.6 \\
\hline & $\begin{array}{c}\text { 塑性指数 } \\
I_{P}\end{array}$ & 4.4 & 17.5 & 26.2 & 15.6 & 22.7 & 18.0 & 15.6 & 45.2 \\
\hline
\end{tabular}

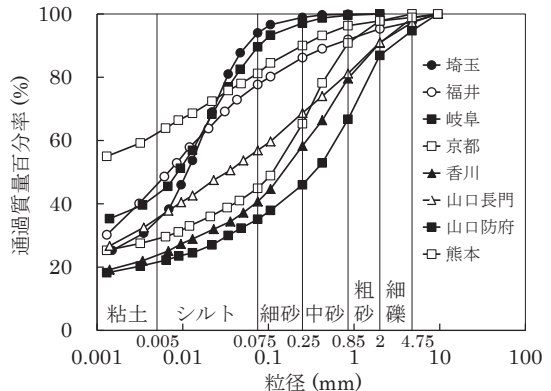

図 1 粒度分布

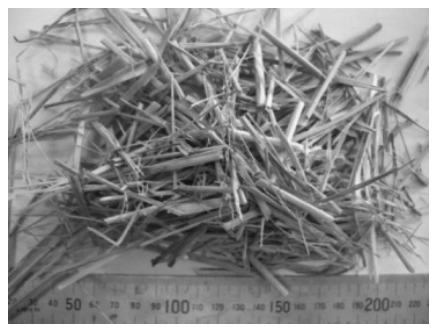

写真 1 葈すさ

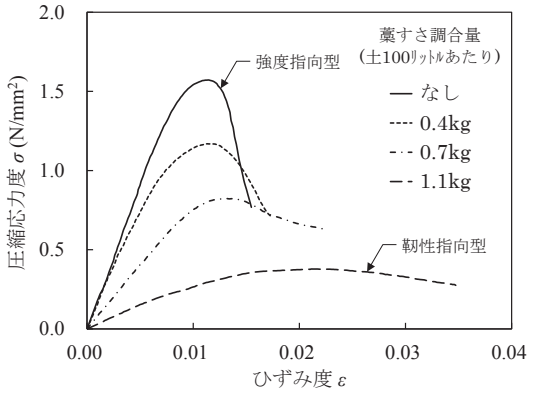

図 2 圧縮応力度一ひずみ度関係

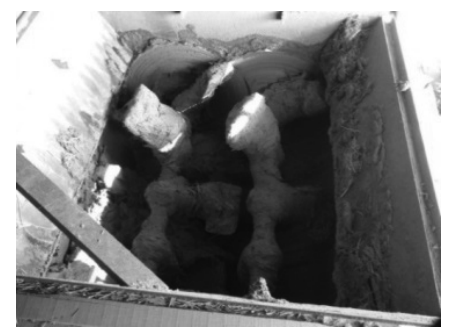

写真 2 ミキサー外観 


$$
\begin{aligned}
& \phi=2 \alpha_{f}-\frac{\pi}{2} \\
& c=\frac{\sigma_{1 f}}{2} \cdot(\sec \phi-\tan \phi)
\end{aligned}
$$

ここで， $\alpha_{f}$ は一軸圧縮試験時の供試体に生じるせん断破壊面の角 度, $\sigma_{1 f}$ は圧縮強度である。ばらつきを考慮して圧縮強度の最大と最 小の試験体を除いた 3 体の平均值で評価を行った。

実験後の供試体に含まれる营すさ調合量を測定するため，水洗い を行い，葈すさと壁土を分離した。分離した葈すさは乾燥炉にて乾 燥させ, 室温 $20^{\circ} \mathrm{C}$, 湿度 $60 \%$ の恒温恒湿器で 24 時間静置した後, 質量測定を行った。

\section{4. 実験結果及び考察}

\section{1 物理特性}

結果を一覧にして表 2 に示す。土粒子密度 $\rho_{s}$ は $2.82 \mathrm{~g} / \mathrm{cm}^{3}$ である。 含水比 $W$ は練り混ぜ直前で $44.0 \%$, 供試体作製時で $64.7 \sim 72.5 \%$,

一軸圧縮試験時で $2.3 \sim 3.6 \%$ ある。葍すさ調合量は一軸圧縮試験後 の測定で，壁土 100 リットルに対し $2.5 \mathrm{~kg}$ 程度である。文献 1)では 荒壁土の標準的な葈すさ調合量は $0.6 \mathrm{~kg}$ であり，4 倍程度の調合量 である。

\section{2 ミキサーの負荷電カ}

図 4 に菜すさ調合後のミキサーの電動機の負荷電力の経時変化を 示す。ここで，負荷電力の值は 10 秒間の移動平均である。葈すさ を投入し, 加水が終わった測定起点直後に電動機の負荷電力は著し く低下寸る。3 分後に 4 回目となる壁土の追加投入が行われ，一時 的に電動機の負荷電力が上昇する。その後，職人の目視による確認 で写真 3 に示寸加水が 3 回行われている。加水直後はミキシングパ ドルと壁土の付着力が低下するため, 一時的に負荷電力が低下寸る。 練り混ぜ開始後 30 分程度までは経時変化とともに負荷電力が緩や かに上昇する傾向を示す。練り混ぜにより水分が粘土粒子相互間に

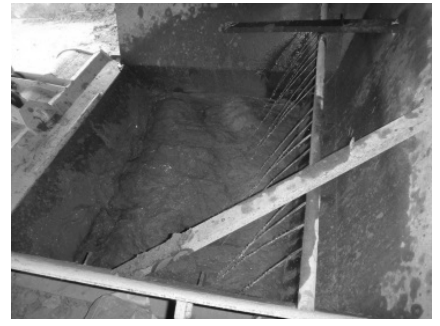

写真 3 加水状況

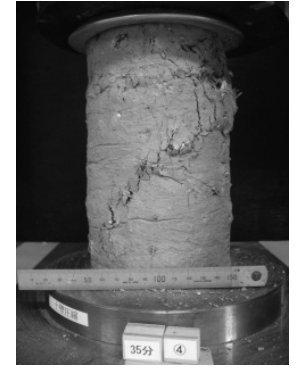

写真 4 一軸圧縮試験

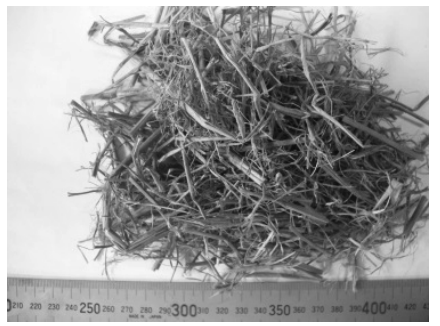

(a) 練り混ぜ開始後 5 分

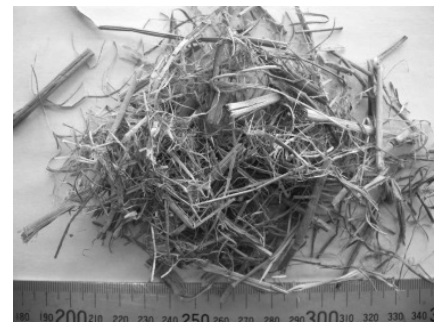

(b) 練り混ぜ開始後 40 分

写真 5 葈すさの経時変化

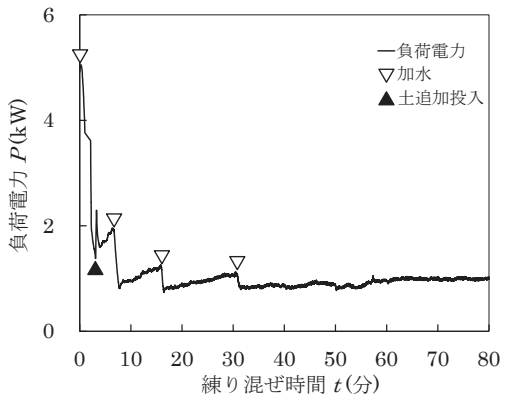

図 4 練り混ぜ時間-負荷電力関係

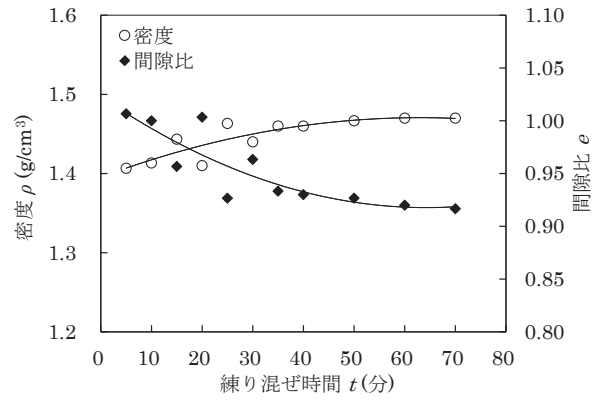

図 5 練り混ぜ時間-密度，間隙比関係 
$\rho$ の変化から葍すさが開繊して供試体中の土粒子の量が増加したこ とが要因と考えられる。圧縮強度以降の応力度低下は, 練り混ぜ時 間の経過に伴って葍すさが開繊し, 繊維補強効果に違いが生じたこ とが要因と考えられる。

図 8 に練り混ぜ時間 $t$ と粘着力 $c$, せん断抵抗角 $\phi$ の関係を示す。 粘性土では界面作用, 吸着水層等により粘着力 $c$ が生じ, 間隙比 $e$ が小さいほど粘着力 $c$ が大きくなる ${ }^{14)}$ 。前述の通り図 5 に示寸間隙 比 $e$ は, 葈すさの開繊により練り混ぜ時間が 40 分程度までは低下 し，それ以降の変化は見られない。図 1 に示寸ように熊本の壁土は 粘土分が $62 \%$ と多く含まれており, 粘土粒子相互は吸着水の水膜を 介して接触するため, 粘性の発現に時間を要する。図 4 から練り混 ぜにより壁土の粘性が増加して負荷電力が上昇し, 土粒子の結合に 寄与するため, 粘着力 $c$ が増加すると考えられる。さらに, 葈すさ の開繊に伴う間隙比 $e$ の低下も粘着力 $c$ の増加に寄与していると考 えられる。せん断抵抗角 $\phi$ は $2 \sim 11^{\circ}$ 範囲で分布し, ばらつきはあ るが増加する傾向を示している。練り混ぜ時間の経過に伴って菜す さが開繊し, 土粒子間の摩擦成分が増加したことが要因と考えられ る。

\section{5 適切な練り混ぜ時間}

本実験で使用した二軸強制練りミキサーの練り混ぜ時間と電動機 の負荷電力の経時変化や粘土分を多く含む壁土の強度特性の関係を 以下にまとめて示す。

・電動機の負荷電力は練り混ぜ開始後 40 分以降では変化が小さい。 ・練り混ぜ開始後 40 分から 50 分で圧縮強度 $\sigma_{u}$ が最大となり, 終 局ひずみ度 $\varepsilon_{r}$ が一定值となり, それ以降の変化が見られない。 ・せん断抵抗角 $\phi$ は練り混ぜ時間の経過に伴って大きくなり, ばら つきはあるものの $10^{\circ}$ 程度の一定值となる。粘着力 $c$ は練り混ぜ 開始後 50 分程度で最大となり, それ以降の変化が見られない。 以上より，本実験の範囲において粘土分を多く含む壁土の適切な 練り混ぜ時間は 50 分程度と考えられる。

\section{5.まとめ}

本研究では, 粘土分を多く含む壁土の適切な練り混ぜ時間の把握 を目的に電力計を用いて二軸強制練りミキサーの負荷電力の測定を 行った。各練り混ぜ時間に対する壁土の一軸圧縮強度試験を行い, 壁土の強度定数の評価を行った。その結果, 以下のことが明らかと なった。

1）二軸強制練りミキサーの負荷電力は壁土の粘性の影響を受け, 練 り混ぜ時間が 40 分以降の変化は小さかった。

2) 練り混ぜにより蒠すさが砂分等の擦れ合せにより開繊し,壁土の
密度が増加した。

3）練り混ぜによる粘性の増加, 葈すさの開繊による供試体の間隙比 の低下, 摩擦成分の増加により, 練り混ぜ時間が 50 分程度まで は壁土の圧縮強度, 粘着力及びせん断抵抗角が増加した。

4) 本実験の範囲における粘土分を多く含む壁土の適切な練り混ぜ 時間は, 電動機の負荷電力の経時変化や壁土の強度特性の関係か ら 50 分程度と考えられる。

\section{謝辞}

本研究は国土交通省の建設技術研究開発助成制度「竹材等の低利用資源を 用いた高性能壁土の開発」の一環として行われた。実験では香川大学，四国 職業能力開発大学校の学生の協力を得た。ここに記して, 感謝の意を表す。

\section{参考文献}

1）日本建築学会: 建築工事標準仕様書·同解説 JASS15 左官工事, pp.74-75, 2008

2）中村伸：日本壁の研究，相模書房，pp.31-34，1954

3）蒲田幸江, 浦憲親, 高山誠, 大塚浩章 : 壁土の品質に関する基礎実験 そ の 4 水合せ, 日本建築学会大会学術講演梗概集, Vol.A-1, pp.513-514, 2001.9

4）濱崎信子, 三芳紀美子, 大橋好光 : 土壁の強度に関する研究 その 3 壁土 圧縮試験, 日本建築学会大会学術講演梗概集, Vol.C-1, pp.399-400, 2004.8

5) 平野陽子, 有馬孝禮, 信田聡: 壁土の練り置き期間に生じる変化が材料特 性に与える影響, 日本建築仕上学会論文報告集, 第 10 巻, 第 1 号, pp.1-7, 2003.1

6）輿石直幸, 田中滋, 位田達哉: 壁土の性質に関する基礎的研究 第 3 報 水 合わせを行った荒壁土の性質について, 日本建築学会大会学術講演梗概集, Vol.A-1, pp.723-724, 2004.8

7）山田宮土理, 奥石直幸, 位田達哉: 壁土の性質に関する基礎的研究 第 7 報 水合せが壁土およびスサに及ぼす影響, 日本建築学会大会学術講演梗 概集, Vol.A-1，pp.653-654，2007.8

8）興石直幸, 位田達哉: 主要産出地における荒壁土および中塗土の性質 小 舞土壁に用いる壁土に関する研究 その 1 , 日本建築学会構造系論文集, No.631, pp.1467-1474, 2008.9

9）山田宮土理，興石直幸：蒠スサを混入した荒壁土および中叙土の性質 小 舞土壁に用いる壁土に関する研究 その 2 , 日本建築学会構造系論文集, No.689, pp.1209-1218, 2013.7

10）山下亮介, 大西泰弘, 小竹望, 山中稔, 宇都宮直樹:建築用壁土の地域別の土 質物理特性について,地盤工学会四国支部平成 24 年度技術研究発表会講演 概要集,pp.65-66,2012.11

11）宇都宮直樹, 松島学: 葈スサを混合した壁土の力学的材料挙動に関する 実験的研究，日本建築学会構造系論文集，No.649, pp.593-596, 2010.3

12）宇都宮直樹, 山中稔, 松島学: 䔅スサを混合した壁土の新しい供試体の 提案, 日本建築学会構造系論文集, No.664, pp.1119-1124, 2011.6

13）土の一軸圧縮試験法, JIS A $1216: 2009$

14）山口柏樹 : 土質力学(全改訂),技報堂出版, pp.142-143, 1984

15）宇都宮直樹, 小林正幸, 宮本慎宏, 山中稳, 松島学: 練り混ぜ時間が壁 土の強度特性に及ぼす影響, 日本建築学会大会学術講演梗概集, 材料施工, pp.899-900, 2013.8

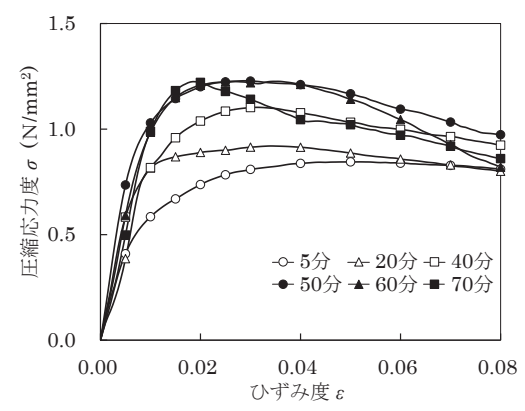

図 6 圧縮応力度-ひずみ度関係

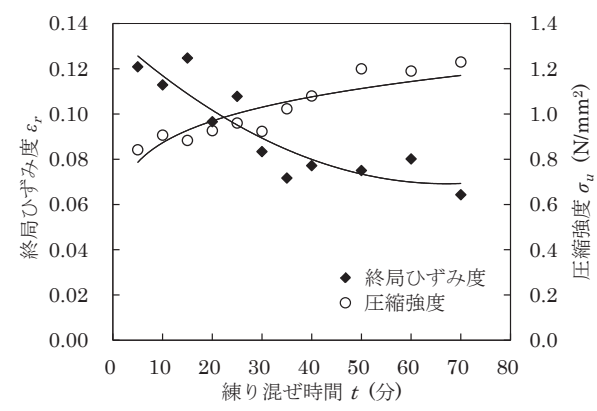

図 7 練り混ぜ時間-終局ひずみ度, 圧縮強度関係

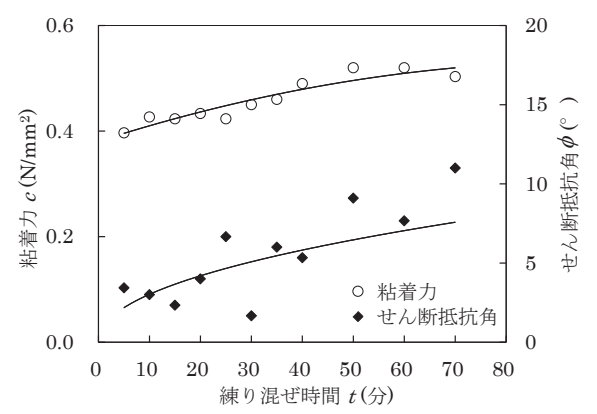

図 8 練り混ぜ時間-粘着力, せん断抵抗角関係

[2013 年 10 月 15 日原稿受理 2013 年 12 月 11 日採用決定］ 